\title{
HUBUNGAN POLA ASUH ORANG TUA DENGAN PERKEMBANGAN SOSIAL ANAK PRASEKOLAH USIA 4-6 TAHUN
}

\author{
The Relationship of Parenting Patterns With Social Development of Preeschool Children \\ 4-6 Years Old
}

\author{
Ratna Sari $^{1}$, Dini Setiarsih ${ }^{2}$ \\ ${ }^{1}$ Program Studi Ilmu Keperawatan Stikes Insan Se Agung
}

${ }^{2}$ Program Studi Gizi, Fakultas Kesehatan, Universitas Nahdlatul Ulama Surabaya

\author{
Alamat Korespondensi : Prodi Ilmu Gizi UNUSA \\ Jl. Raya Jemursari No. 51-57 Kec. Wonocolo Surabaya, Jawa Timur - Indonesia \\ e-mail: dinisetiarsih@unusa.ac.id
}

\begin{abstract}
ABSTRAK
Pengasuhan orang tua akan memberikan perlakuan yang berbeda-beda. Sikap dan perlakuan orang tua pada anaknya akan menjadi kebiasaan pula bagi anak-anaknya. Hal ini juga akan berpengaruh pada perkembangan anak. Tujuan penelitian adalah mengetahui hubungan pola asuh orang tua dengan perkembangan sosial anak prasekolah usia 4-6 tahun di TK Nurul Ulum Bangkalan.

Jenis penelitian ini adalah analitik dengan desain penelitian cross sectional. Populasi adalah semua ibu di TK Nurul Ulum dengan anak usia $4-6$ tahun sebanyak 60 orang dan besar sampel sebanyak 56 orang. Teknik pengambilan sampel yang digunakan adalah simple random sampling. Variabel independen yaitu pola asuh ibu sedangkan variabel dependen yaitu perkembangan sosial anak. Pengumpulan data menggunakan kuesioner. Analisa data menggunakan Uji Statistic Lambda.

Hasil penelitian menunjukkan persentase terbesar orang tua anak di TK Nurul Ulum menerapkan pola asuh permisif yaitu sebayak 20 orang $(35,7 \%)$. Perkembangan sosial anak dengan persentase terbesar adalah baik yaitu sebanyak 27 anak (48,2\%). Hasil uji statistik Lambda menunjukkan ada hubungan bermakna antara pola asuh orang tua terhadap anak dengan perkembangan sosial anak prasekolah usia $4-6$ tahun di TK Nurul Ulum Bangkalan $(p=0.01)$. Pola asuh permisif menunjukkan hasil perkembangan sosial anak yang baik dibandingkan otoriter dan otoritatif.

Setiap orang tua memiliki cara tersendiri untuk mendidik anaknya, namun pola asuh yang tepat sangat diperlukan untuk proses perkembangan anak. Sehingga diharapkan untuk para orang tua memiliki pengetahuan tentang pola asuh yang tepat untuk anaknya, dan mengaplikasikan pola asuh yang sesuai dengan umur anak, tanpa melupakan hak dan keinginan anak.
\end{abstract}

Kata kunci : pola asuh, perkembangan sosial, anak prasekolah

Parenting will provide different treatment. The attitude and treatment of parents to their children will also become a habit for their children. It also will influence the development of children. The aims of this research is to analyse the relationship parenting of parenting patterns with social development of preschool children 4-6 years old at TK Nurul Ulum Bangkalan.

This research was an analytical, cross sectional study of mother in TK Nurul Ulum with children aged 4-6 years ( 60 people). The 56 sample was chosen at random. The independent variabel was the parenting patterns. The dependent variable was social development of children. Data collection by interview used questionnaire. The data was analysed using Lambda test.

The highest percentage is permissive parenting (35.7\%). The social development of children with the largest percentage is good (48.2\%). There was a significant relationship between parenting patterns with the social development of preschool children aged 4-6 years at TK Nurul Ulum Bangkalan $(p=0,01)$. Permissive parenting shows good results in children's social development compared to authoritarian and authoritative parenting 
Every parent has their own way of educating their children, but proper parenting is necessary for the child's development process. So it is expected that parents have knowledge about appropriate parenting styles for their children, and apply parenting patterns that are appropriate for the child's age, without forgetting the rights and desires of the child.

Keywords : parenting, social development, preschool children

PENDAHULUAN

Pola asuh orang tua dan perkembangan anak dalam kehidupan bermasyarakat itu akan bergantung bagaimana dengan orangorang di sekitar lingkungan mereka berada, lebih-lebih kedua orang tuanya. Hal itu akan menententukan kepribadian anak untuk kehidupannya di masa mendatang. Peranan aktif dari orang tua dan lingkungan merupakan usaha yang tepat dalam mengembangkan potensi anak secara optimal.Namun faktanya masih banyak orang tua yang tidak memperdulikan anaknya.Banyak orang tua memilih untuk menitipkan anaknya kepada seorang pengasuh. Dan tidak semua pengasuh anak memiliki kemampuan untuk memberikan informasi dan pelajaran yang baik pada anakanak, dan akhirnya anak akan mengikuti semua yang diajari oleh pengasuhnya dan bahkan terkadang dapat mengganggu perkembangan anak.

Seorang anak dapat mengalami keterlambatan perkembangan di hanya satu ranah perkembangan saja, atau dapat pula di lebih dari satu ranah perkembangan. Keterlambatan perkembangan umum atau global developmental delay merupakan keadaan keterlambatan perkembangan yang bermakna pada dua atau lebih ranah perkembangan.Sekitar 5 hingga 10\% anak diperkirakan mengalami keterlambatan perkembangan. Data angka kejadian keterlambatan perkembangan umum belum diketahui dengan pasti, namun diperkirakan sekitar 1-3\% anak di bawah usia 5 tahun mengalami keterlambatan perkembangan social (Medise, 2013).

Hasil dari Survey Bavarian Pre-School Morbidity Survey (BPMS) pada anak prasekolah dari tahun 2003 - 2009 terjadi peningkatan keterlambatan perkembangan sosial yang signifikan dari $4,07 \%$ menjadi $22,05 \%$ antara tahun $2003-2009$. Penelitian yang dilakukan di ekuador tahun 2003 2004 , tercatat $28,1 \%$ anak mengalami keterlambatan perkembangan sosial pada anak usia 48 - 61 bulan, sedangkan jurnal penelitian di Indonesia yang diambil dari 2 rumah sakit di Jakarta tercatat 11,3\% anak mengalami keterlambatan perkembangan social (Widati, 2012).

Di Indonesia, data mengenai penyimpangan perkembangan sosial anak prasekolah belum terdata secara akurat dan spesifik. Namun sekitar 5 hingga 10\% anak diperkirakan mengalami keterlambatan perkembangan social (Medise, 2013). Di Randosari Bojolali menunjukkan 15\% anak usia prasekolah mengalami ketidaksesuaian perkembangan social (Ernawati, 2014). Menunjukkan 35,3\% anak usia 3-6 tahun dengan pendidikan usia dini di Kecamatan Peterongan Jombang mengalami 
perkembangan sosial yang tidak sesuai (Wulandari, 2016).

Salah satu faktor yang mempengaruhi perkembangan anak adalah keberfungsian keluarga. Apabila dalam keluarga tidak bisa/mampu menerapkan atau melaksanakan fungsi-fungsi keluarga, maka keluarga tersebut berarti mengalami stagnasi (kemandegan) atau disfungsi yang pada gilirannya akan merusak kekokohan konstelasi keluarga tersebut, khususnya terhadap perkembangan anak (Yusuf, 2016).

Cara dan pola asuh orang tua akan berbeda antara keluarga yang satu dengan keluarga yang lain. Pola hubungan orang tua dan anak (sikap dan perlakuan orang tua terhadap anak) juga sangat mempengaruhi perkembangan anak. Dalam kegiatan memberikan pengasuhan ini, orang tua akan memberikan perlakuan yang berbeda-beda. Sikap, perilaku dan perlakuan orang tua pada anaknya yang kemudian semua itu secara sadar atau tidak sadar diresapi kemudian menjadi kebiasaan pula bagi anak-anaknya. Hal ini juga akan berpengaruh pada perkembangan anak (Ismira, 2008).

Penting bagi orang tua untuk melakukan deteksi dini supaya bisa mengetahui kelainan-kelainan pada perkembangan anaknya sejak dini untuk mencegah keterlambatan perkembangan yang tidak sesuai dengan umur dan masa perkembangan. Salah satu upaya untuk mengoptimalkan perkembangan yakni dengan menerapkan pola asuh yang sesuai dan baik, dengan adanya sifat terbuka antara orang tua dan anak.Oleh karena itu, penelitian ini dilakukan untuk mengetahui hubungan pola asuh orang tua dengan perkembangan sosial anak prasekolah usia 4-6 tahun di TK Nurul Ulum Bangkalan.

\section{METODE}

\section{Desain Penelitian}

Desain dalam penelitian ini adalah Cross Sectional yaitu penelitian dengan melakukan pengukuran atau pengamatan pada saat bersamaan (sekali waktu) (Hidayat, 2010). Survey cross sectional merupakan suatu penelitian untuk mempelajari dinamika korelasi antara faktor-faktor resiko dengan efek, dengan cara pendekatan observasi atau pengumpulan data sekaligus pada suatu saat (Point Time Approach). Tiap subjek penelitian hanya diobservasi sekali saja dan pengukuran variable independen dan dependen dilakukan pada saat pemeriksaan atau pengkajian data (Nursalma, 2011).

\section{Populasi dan Sampel}

Populasi dalam penelitian ini adalah semua orang tua dengan anak usia 4-6 tahun di TK Nurul Ulum Bangkalan yaitu sebanyak 60 orang. Besar sampel pada penelitian ini adalah 56 orang. Teknik pengambilan sampel pada penelitian ini menggunakan simple random sampling, yaitu pengumpulan sampel yang didasarkan atas kesempatan untuk terpilih atau tidak terpilih sebagai sampel (Heriyanto, 2012).

\section{Variabel Penelitian}

1. Variabel Independen dalam penelitian ini adalah Pola Asuh Ibu Terhadap Anak 
2. Variabel Dependen dalam penelitian ini adalah Perkembangan Sosial Anak

HASIL DAN PEMBAHASAN

\section{Data Umum}

Tabel 1. Distribusi Frekuensi Umur Ibu Di TK Nurul Ulum Bangkalan

\begin{tabular}{ccc}
\hline Umur Ibu & Frekuensi & $\begin{array}{c}\text { Presentase } \\
(\mathbf{\%})\end{array}$ \\
\hline $21-22$ & 7 & $12,5 \%$ \\
\hline $23-24$ & 8 & $14,8 \%$ \\
\hline $25-26$ & 11 & $19,6 \%$ \\
\hline $27-28$ & 8 & $14,3 \%$ \\
\hline $29-30$ & 9 & $16,1 \%$ \\
\hline $31-32$ & 4 & $7,5 \%$ \\
\hline $33-34$ & 3 & $5,3 \%$ \\
\hline $35-36$ & 6 & $10,8 \%$ \\
\hline Total & $\mathbf{5 6}$ & $\mathbf{1 0 0}$ \\
\hline
\end{tabular}

Dari Tabel 1 menunjukkan bahwa presentase terbesar ibu berusia 25 - 25 tahun yaitu sebanyak $11 \mathrm{ibu}(19,6 \%)$.

Tabel 2. Distribusi Frekuensi Umur Anak di TK Nurul Ulum Bangkalan

\begin{tabular}{ccc}
\hline Umur Anak & Frekuensi & Presentase (\%) \\
\hline 4 Tahun & 11 & $19,6 \%$ \\
\hline 5 Tahun & 25 & $44,6 \%$ \\
\hline 6 Tahun & 20 & $35,7 \%$ \\
\hline Total & $\mathbf{5 6}$ & $\mathbf{1 0 0}$
\end{tabular}

Berdasarkan Tabel 2 menunjukkan bahwa presentase terbesar umur anak yang ada di TK Nurul Ulum bangkalan adalah 5 tahun dengan jumlah 25 anak (44,6\%).

Tabel 3. Distribusi Frekuensi Urutan Anak di TK Nurul Ulum Bangkalan

\begin{tabular}{ccc}
\hline Urutan Anak & Frekuensi & $\begin{array}{c}\text { Presentase } \\
\mathbf{( \% )}\end{array}$ \\
\hline Anak Pertama & 17 & $30,4 \%$ \\
\hline Anak Kedua & 20 & $35,7 \%$ \\
\hline Anak Kegita/lebih & 19 & $33,9 \%$ \\
\hline Total & $\mathbf{5 6}$ & $\mathbf{1 0 0}$ \\
\hline
\end{tabular}

Berdasarkan Tabel 3 menunjukkan bahwa presentase terbesar siswa TK Nurul
Ulum Bangkalan adalah anak kedua dengan jumlah 20 anak (35,7\%).

Tabel 4. Distribusi Jumlah Saudara Anak di TK Nurul Ulum Bangkalan

\begin{tabular}{ccc}
\hline Anak Ke & Frekuensi & $\begin{array}{c}\text { Prosentase } \\
(\mathbf{\%})\end{array}$ \\
\hline Anak Tunggal & 19 & $34 \%$ \\
\hline 2 Bersaudara & 16 & $28,5 \%$ \\
\hline 3 Bersaudara & 16 & $28,5 \%$ \\
\hline 4 Bersaudara & 5 & $9 \%$ \\
\hline Total & $\mathbf{5 6}$ & $\mathbf{1 0 0}$ \\
\hline
\end{tabular}

Berdasarkan Tabel 4 menunjukkan bahwa presentase terbesar siswa TK Nurul Ulum Bangkalan adalah anak tunggal dengan jumlah 19 anak (34\%).

2. Data Khusus

Tabel 5. Distribusi Frekuensi Pola Asuh Orang Tua di TK Nurul Ulum Bangkalan

\begin{tabular}{ccc}
\hline Pola Asuh & Frekuensi & Presentase (\%) \\
\hline Permisif & 20 & $35,7 \%$ \\
\hline Otoriter & 19 & $33,9 \%$ \\
\hline Otoritatif & 17 & $30,4 \%$ \\
\hline Total & $\mathbf{5 6}$ & $\mathbf{1 0 0}$ \\
\hline
\end{tabular}

BerdasarkanTabel 5 menunjukkan bahwa pola asuh yang diterapkan oleh orang tua di TK Nurul Ulum persentase terbesar adalah menerapkan pola asuh Permisif dengan jumlah 20 responden $(35,7 \%)$.

Tabel 6. Distribusi Frekuensi Perkembangan Sosial Anak Prasekolah Usia 4-6 tahun di TK Nurul Ulum Bangkalan

\begin{tabular}{ccc}
\hline $\begin{array}{c}\text { Perkembangan } \\
\text { Anak }\end{array}$ & Frekuensi & $\begin{array}{c}\text { Presentase } \\
(\mathbf{\%})\end{array}$ \\
\hline Baik & 27 & $48,2 \%$ \\
\hline Cukup & 19 & $33,9 \%$ \\
\hline Kurang & 10 & $17,9 \%$ \\
\hline Total & $\mathbf{5 6}$ & $\mathbf{1 0 0}$ \\
\hline
\end{tabular}

Berdasarkan Tabel $6 \quad$ dapat disimpulkan bahwa presentase terbesar 
perkembangan sosial anak adalah baik dengan jumlah 27 anak (48,2\%).

Tabel 7. Hasil Tabulasi Silang Pola Asuh Orang Tua terhadap Anak dengan Perkembangan Sosial Anak Prasekolah usia 4-6 tahun di TK Nurul Ulum Bangkalan

\begin{tabular}{cccccccccc}
\hline \multirow{2}{*}{$\begin{array}{c}\text { Pola Asuh } \\
\text { Orang } \\
\text { Tua }\end{array}$} & \multicolumn{4}{c}{ Perkembangan Anak } & \multicolumn{2}{c}{ Total } \\
\cline { 2 - 8 } & \multicolumn{2}{c}{ Baik } & \multicolumn{3}{c}{ Cukup } & \multicolumn{2}{c}{ Kurang } & \multirow{2}{*}{ F } & \% \\
\hline Permisif & 12 & 60 & 8 & 40 & 0 & 0 & 20 & 100 \\
\hline Otoriter & 8 & 42 & 6 & 31 & 5 & 27 & 19 & 100 \\
\hline Authoritative & 7 & 42 & 5 & 29 & 5 & 29 & 17 & 100 \\
\hline Total & 27 & 48 & 19 & 34 & 10 & 18 & 56 & 100 \\
\hline
\end{tabular}

Dari hasil tabulasi silang pada Tabel 7 menunjukkan bahwa dari 20 orang tua yang menerapkan pola asuh permisif, 12 anak $(60 \%)$ mengalami perkembangan sosial yang baik dan 8 anak (40\%) mengalami perkembangan sosial yang cukup.

Berdasarkan hasil dari uji statistic lambda dengan menggunakan spss diperoleh hasil signifikan $0,01<0,05$ yang berarti terdapat hubungan yang signifikan antara pola asuh orang tua terhadap anak dengan perkembangan sosial anak usia 4-6 tahun di TK Nurul Ulum Bangkalan.

\section{PEMBAHASAN}

\section{Pola Asuh Orang Tua}

Berdasarkan Tabel 4 menunjukkan bahwa pola asuh yang diterapkan oleh orang tua di TK Nurul Ulum sebagian besar adalah menerapkan pola asuh Permisif dengan jumlah 20(35,7\%).

Pola asuh merupakan pola interaksi antara orang tua dan anak, yaitu bagaimana cara sikap atau perilaku orang tua saat berinteraksi dengan anak. Pola asuh orang tua ada tiga, yaitu otoriter, otoritatif, dan permisif. Pola asuh otoriter adalah pola asuh yang sikapnya memberikan komando, bersikap kaku dan cenderung keras. Kemudian pola asuh otoritatif adalah pola asuh yang memiliki sikap responsife terhadap kebutuhan anak, serta mendorong anak untuk menyatakan pendapatnya.Sedangkan pola asuh permissive adalah pola asuh yang cenderung memberikan kebebasan kepada anaknya sehingga anak lebih sering memberontak.

Salah satu faktor yang mempengaruhi pola asuh orang tua adalah jumlah anak. Jumlah anak mempengaruhi pola asuh orang tua kepada anaknya. Orang tua yang memiliki anak hanya 2-3 orang (keluarga kecil) cenderung lebih intensif pengasuhannya, dimana interaksi antara orang tua dan anak lebih menekankan pada perkembangan pribadi dan kerja sama antar anggota keluarga lebih diperhatikan. Sedangkan orang tua yang memiliki anak berjumlah lebih dari 5 orang (keluarga besar) sangat kurang memperoleh kesempatan untuk mengadakan kontrol secara intensif antara orang tua dan anak, karena orang tua secara otomatis berkurang perhatiannya pada setiap anak (Hurlock, 2012).

Sesuai dengan teori di atas dalam penelitian ini jumlah anak dapat menjadi faktor yang mempengaruhi pola asuh orang tua.Orang tua dengan anak lebih dari dua ternyata cenderung memiliki pola asuh yang permisif.Orang tua cenderung menggantungkan diri pada penalaran dan manipulasi, tidak menggunakan kekuasaan terbuka, sehingga agak lebih bebas 
melakukan

sesuatu

sesuai

keinginannya.Orang tua dianggap berkuasa dan tidak membimbing anak untuk patuh pada semua perintah orang tuanya.

Kebebasan yang berlebihan seperti ini tidak sesuai dengan perkembangan anak yang dapat menyebabkan anak menjadi umpulsif dan agresif. Sementara untuk pola asuh authoritative, orang tua dengan jumlah anak kurang dari dua lebih besar persentasenya dibandingkan orang tua dengan anak lebih dari dua. Ditandai dengan dukungan emosional yang tinggi, komunikasi yang terbuka, standar yang tinggi, dan jaminan kemandirian sehubungan dengan kompetensi anak. Anak yang diasuh menggunakan model pola asuh ini dapat memiliki kepercayaan terhadap kemampuan, dan dapat mengembangan keterampilannya.

Hal tersebut dapat terjadi karena orang tua mungkin mengalami kesulitan dalam memberikan perhatian yang lebih pada masing-masing anak. Sehingga orang tua dengan anak lebih dari dua cenderung memberikan kebebasan pada anak dalam berperilaku.

\section{Perkembangan Sosial Anak Prasekolah}

Berdasarkan Tabel 5 dapat disimpulkan bahwa sebagian besar perkembangan sosial anak adalah baik dengan jumlah 27 anak (48,2\%). Pada penelitian ini, parameter yang diteliti yaitu pernyataan berikut ini: suka belajar bersama teman-teman, lebih suka bekerja dan bermain sendiri, mudah tersinggung dan cepat marah, takut menghadapi sesuatu atau masalah baru, berbohong, mau menerima nasihat dari orang lain, mampu beradaptasi dengan lingkungan baru, mudah merasa senang/sedih ketika teman merasa senang/sedih, mampu bercerita di depan teman-teman disekolah, dan yang terakhir adalah tidak mau meminjamkan barang kepada teman-temannya. Dari 10 parameter yang diteliti, jawaban yang tidak menunjukkan perkembangan perilaku yang diharapkan adalah No 5 berbohong (60,7\% menjawab iya) dan No 10 tidak mau meminjamkan barang kepada temannya (62,5\% menjawab iya).

Kemudian perilaku yang tidak menunjukkan perilaku perkembangan yaitu pada pernyataan no 5 yaitu berbohong. Teori menjelaskan bahwa anak yang impulsif bertindak secara spontan secara mendadak, memaksa, dan tidak sengaja. Anak usia prasekolah masih wajar melakukan beberapa perilaku impulsif mengingat kematangan kognitif dan emosinya msih belum berkembang sepenuhnya. Namun untuk kasus-kasus yang ekstrim, impulsifitas dapat disebabkan oleh penyebab organik, kecemasan (karena cemas tidak dapat berpikir rasional) dan pengaruh budaya atau pengasuhan (Mittman, 2008).

Pada penelitian ini anak yang suka berbohong adalah anak yang masih mengalami masalah yang berupa impulsif yang menunjukkan pada sifat anak yang bertindak secara spontan dan mendadak, memaksa, dan tidak sengaja. Misalnya untuk menutupi kesalahan yang diperbuatnya, anak memilih untuk menutupi kesalahannya dengan berbohong. 
Perilaku anak sepenuhnya bergantung pada bagaimana cara orang tua mendidik dan membesarkan anak. Berbohong atau tidak berkata jujur adalah salah satu hal dasar yang biasanya akan dengan mudah berkembang pada setiap anak. Bahkan ketika tidak sedang melakukan kesalahan, anak-anak terkadang akan belajar melakukan kebohongan baik itu dari teman atau dari lingkungan sekitar yang dapat memberikan pengaruh terhadap sikap dn pembentukan karakter seorang anak.

Orang tua dapat dengan mudah mengetahui anaknya berbohong atau tidak. Gelisah merupakan perilaku yang dapat dilihat ketika anak sedang berbohong. Jika mereka terlihat gelisah atau tidak tenang serta menggeliat saat melontarkan alasan, maka ini dapat berarti bahwa mereka mengatakan suatu kebohongan. Begitupun ketika anak cenderung diam tak banyak bicara. Hal ini bisa menandakan bahwa anak sedang menutupi sesuatu yang tidak ingin diketahui oleh orang tua. Kebohongan biasanya akan dimulai ketika anak berada pada masa sekolah, alasan yang dituaipun hampir serupa dengan orang dewasa, untuk mendapatkan perhatian atau ketika mereka merasa takut menerima akibat dari perbuatan yang telah dilakukannya.

Beberapa masalah umum yang terjadi pada anak usia prasekolah antara lain menarik diri. Anak yang menarik diri tidak mau terlihat dalam kontak sosial dengan temannya. Hal ini dapat dipengaruhi oleh masalah lain seperti kesulitan bersekolah, gangguan kepribadian, dan masalah-masalah emosional. Anak-anak menarik diri disebabkan karena rasa takut terhadap orang lain, keterampilan sosial seperti antri, berbagi, menyumbangkan ide, atau orang tua yang tidak suka pada teman sebayanya (Radhy, 2011).

Pada penelitian ini masih ada sebagian anak yang lebih memilih untuk tidak bergaul dengan temannya, mereka lebih memilih asyik dengan dunianya sendiri tanpa memperdulikan orang lain. Anak yang lebih memilih untuk menarik diri dari orang lain, biasanya cenderung penakut dan hanya mau bergaul dengan orang tuanya saja. Hal ini sesuai dengan teori yang menjelaskan bahwa anak-anak yang menarik diri bisa juga terjadi pada anak-anak yang terlalu pandai atau terlalu kreatif. Cara berfikir yang berbeda membuat teman-teman seusianya tidak dapat menerim mereka sehingga ia merasa terkucilkan dan akhirnya anak tersebut menarik diri dari pergaulan dengan temanteman sebayanya (Radhy, 2011).

Egois adalah sifat yang alami melekat pada anak-anak usia dini, dunia mereka berpusat pada dirinya sendiri, mereka menuntut lingkungan untuk memenuhi keinginannya. Sifat egois bukanlah sifat bawaan atau turunan, tapi masalah pembiasaan. Perkembangan sosial seorang anak dipengaruhi oleh lingkungannya, baik dari orang tua maupun orang-orang disekitarnya.

Pada penelitian ini anak yang tidak mau meminjamkan barang pada orang lain termasuk anak yang egois. Anak yang egois hanya peduli dengan dirinya sendiri, hanya berfokus ada kesejahteraan dirinya sendiri 
tanpa peduli orang lain. Penyebab perilaku egois dapat dikarenakan ketakutan, seperti takut dekat dengan orang lain, takut ditolak, dan takut perubahan.Anak yang banyak merasakan ketakutan seringkali memandang berbagai perubahan dalam hidupnya sebagai sesuatu yang mengancam dirinya.

\section{Hubungan Pola Asuh Orang Tua Terhadap Anak Dengan Perkembangan Anak Prsekolah Usia 4 -6 Tahun}

Hasil dari uji statistic lambda menunjukkan nilai $\mathrm{p}=0,01<0,05$ yang berarti terdapat hubungan yang signifikan antara pola asuh orang tua terhadap anak dengan perkembangan sosial anak usia $4-6$ tahun di TK Nurul Ulum Bangkalan.

Apabila orang tua menerapkan pola asuh yang tepat maka akan mempengaruhi kemampuan sosialisasinya, karena anak hidup dalam keluarga yang selalu mendukungnya dalam cinta kasih, sehingga anak bisa tumbuh dan berkembang secara optimal. Pola asuh orang tua ada tiga, yaitu otoriter, demokratis, dan permisif.

Pada pola asuh permisif orang tua serba membolehkan anak berbuat apa saja, tidak terlalu menuntut dan tidak mengontrol mereka serta cenderung memanjakan. Orang tua yang memliki pola asuh permisif sikap orang tua cenderung serba memperbolehkan, namun kontrolnya rendah, disiplin yang longgar, orang tua memanjakan anak, memberikan kepercayaan penuh kepada anak, segala keinginan anak selalu dipenuhi, orang tua jarang bahkan tidak memberikan pengarahan, peraturan dan pembatasan terhadap sikap yang dilakukan anak secara penuh, orang tua cenderung tidak peduli dan membiarkan anak. Efek pengasuhan pola asuh permisif yaitu anak kurang memiliki rasa hormat pada orang lain dan mengalami kesulitan dalam mengendalikan perilakunya. Kemungkinan mereka juga mendominasi, egosentris, tidak menuruti aturan (Soetjiningsih, 2012).

Sementara itu pada usia prasekolah, minat anak terhadap teman sepermainan yang berusia sebaya semakin bertambah dan kesenangan yang mereka peroleh dari pergaulan ini semakin kuat. Hubungan yang positif antara anak dengan orang dewasa akan memberikan dasar untuk mereka belajar. Hubungan yang dibangun sejak dini memiliki dampak yang kuat terhadap perkembangan anak, melalui hubungan tersebut anak-anak akan terampil untuk terlibat dengan orang lain dan lebih adaptif jika memasuki lingkungan yang baru. Anak akan belajar mengelola emosi dan perilaku mereka dan anak-anak akan mudah bergaul dengan teman sebayanya bahkan dengan orang yang lebih dewasa. Mereka akan mudah menyesuaikan diri dengan situasi baru dan mampu menyelesaikan konflik (Hurlock, 2012).

Pada penelitian ini didapatkan hubungan yang signifikan antara pola asuh orang tua dengan perkembangan sosial anak prasekolah. Arah hubungan pola asuh orang tua dengan perkembangan anak memiliki arah hubungan yang positif. Namun pada penelitian ini kecenderungan yang terjadi adalah arah hubungan yang negatif. Oleh 
karena itu, sejalan dengan teori Hurlock (2012) di atas, maka walaupun orang tua memiliki pola asuh permisif namun perkembangan sosial anak baik. Hal tersebut mungkin dikarenakan anak-anak tersebut menjalani pendidikan prasekolah di TK. Dan di TK tersebut banyak berinteraksi dengan teman sebayanya. Pada dasarnya hubungan dengan anak lain kebanyakan hanya untuk bermain. Walaupun bermain tidak memiliki tujuan yang jelas namun dengan bermain anak akan dapat mengekpresikan dirinya dengan lingkungan disekitarnya. Interaksi ini dapat membentuk kemampuan sosialisasi anak karena anak dibiasakan dapat berinteraksi dengan orang lain dan bertindak sebagai dukungan emosional. Ineraksi anak dengan anak lain diluar anggota keluarga memberikan kesempatan untuk berbaur dengan mereka yang berstatus sama serta mengembangkan kemampuan sosial anak dalam bermasyarakat kelak.

\section{PENUTUP}

\section{Kesimpulan}

Berdasarkan analisa data dan pembahasandapat disimpulkan bahwa:

1. Pola asuh yang diterapkan oleh orang tua di TK Nurul Ulum Bangkalan adalah permisif $(35,7 \%)$.

2. Perkembangan sosial anak di TK Nurul Ulum Bangkalan adalah baik (48,2\%)

3. Ada hubungan antara pola asuh orang tua dengan perkembangan sosial anak prasekolah usia 4-6 tahun di TK Nurul Ulum Bangkalan.

\section{Saran}

1. Bagi Tenaga Kesehatan

Bagi petugas kesehatan diharapkan dapat memberikan informasi tentang pentingnya memberikan pola asuh yang tepat kepada anak, karena anak akan mengikuti setiap hal yang dilakukan oleh orang tuanya.

2. Bagi orang Tua

Diharapkan agar orang tua mampu memilih dan memberikan pola asuh yang sesuai kepada anaknya, sehingga anak akan tumbuh dan berkembang dengan baik.

3. Bagi Peneliti Selanjutnya

Diharapkan untuk melakukan penelitian lebih lanjut dengan analisa yang lebih baik. Disamping itu, disarankan dapat mencari variabel yang lain tentang faktor yang mempengaruhi perkembangan sosial anak selain pola asuh dari orang tua.

\section{DAFTAR PUSTAKA}

Ernawati (2014). Pengaruh Keikutsertakan Pendidikan Di Paud Terhadap Perkembangan Personal Sosial anak 3-4 Tahun Skripsi Sarjana Keperawatan, Stikes Karya Husada Semarang

Heriyanto, B. (2012). Metode Penelitian Kuantitatif Teori dan Aplikasi. Surabaya: Putra Media Nusantara.

Hidayat, A. A. A. (2010). Riset Keperawatan dan Teknik Penulisan Ilmiah. Jakarta: Salemba Medika

Hurlock, E. B. (2012). Perkembangan Anak Jilid 1. Jakarta: Erlangga

Ismira, D. (2008). Mengenal Bentuk Pola Asuh Orang Tua. Jakarta: Medika Cipta. 
Medise, B.E (2013). Mengenal keterlambatan perkembangan umum pada anak diakses 14 februari 2017, dari Ikatan Dokter Anak Indonesia www.Idai.co.id

Mittman, (2008). Menumbuhkan Kemandirian Pada Anak. Tersedia dalam: $\quad$ http://www.tabloidnakita.com . diakses pada 20 September 2016

Nursalam (2011). Konsep dan Penerapan Metodologi Penelitian Ilmu Keperawatan; Pedoman Skripsi, Tesis, dan Instrumen Penelitian Keperawatan. Jakarta: Salemba Medika
Radhy, M. S. (2011). Perkembangan Perserta Didik. Parepare: Fakultas Keguruan Universitas Indonesia

Widati, (2012). Buku Ajar Keperawatan Pediatric, Volume 2. Jakarta: EGC

Wulandari, R (2016). Perbedaan Perkembangan Sosial Anak Usia 36 Tahun Dengan Pendidikan Usia Dini Dan Tanpa Pendidikan Usia Dini Di Kecamatan Peterongan Jombang Skripsi Sarjana Fakultas Kedokteran Universitas Muhammadiyah Surakarta

Yusuf, S. (2016). Psikologi Perkembangan Anak \& Remaja. Bandung: PT Remaja Rosdakarya. 